\title{
Do the Commons Help Augment Mutual Insurance among the Poor?
}

\author{
Yoshito Takasaki \\ Graduate School of Humanities and Social Sciences \\ University of Tsukuba \\ 1-1-1 Tennodai, Tsukuba \\ Ibaraki 305-8571 Japan \\ Tel./fax.: +81298536280 \\ E-mail address: takasaki@sk.tsukuba.ac.jp
}

May 27, 2010

Forthcoming in World Development 


\title{
Do the Commons Help Augment Mutual Insurance among the Poor?
}

\author{
Abstract \\ Poor people rely on local commons not only for self-insurance, as commonly found, but \\ also for mutual insurance, depending on resources and shocks. This paper demonstrates \\ that this conjecture holds among cyclone victims in the Pacific Islands. On one hand, \\ households increase coastal fishing and handicraft selling, but not forest-product \\ gathering, to smooth income against own crop damage. On the other hand, households \\ with undamaged housing intensify fishing to help other kin-group members with \\ damaged housing. These distinct patterns of using commons as insurance are explained \\ by distinct forms of risk sharing against these two shocks.
}

Keywords: commons, self-insurance, mutual insurance, Pacific, Fiji 


\section{Acknowledgments}

I wish to thank my field team - Jonati Torocake, Viliame Manavure, Viliame Lomaloma, Maria Torocake, and Anaseini Savuiwasa - for their advice, enthusiasm, and exceptional efforts on behalf of this project. Special thanks are owed to the Fijians of the region who so willingly participated in the survey. Xiaowen Mo undertook the laborious task of data entry and cleaning. This research has been made possible through support provided by the Sumitomo Foundation, the Japan Society for the Promotion of Science, and the Ministry of Education, Culture, Sports, Science and Technology in Japan. Any errors of interpretation are solely the author's responsibility. 


\section{Do Commons Help Mutual Insurance?}

\section{INTRODUCTION}

Do poor people in developing areas rely on local commons to cope with adverse shocks? This question of "natural insurance” has received explicit attention among economists since the 1980s (e.g., Jodha, 1986), and recent systematic works based on micro survey data provide supportive evidence (e.g., Fisher and Shively, 2005; Hunter et al., 2007; McSweeney, 2005; Pattanayak and Sills, 2001). Theoretical works highlight the advantages of commons as a safety net, especially among the poor with limited coping options: Resource use is usually not so risky, it is often uncorrelated with shocks to primary activities like farming, and individual returns to it vary little across households. Baland and Francois (2005) demonstrate that even if a resource is equitably privatized, commons can have better insurance properties than insurance markets with information and enforcement problems. Delacote's (2007) related theoretical work examines how the insurance role of tropical forests is related to deforestation. The natural insurance concept has led to an increasing recognition that environmental conservation is important for the poor, not only for income earnings but also as a safety net (Angelsen and Wunder, 2003).

Previous works on natural insurance, or, more generally, ex post labor supply, focus on its role as self-insurance against households’ own shocks: With greater adverse shocks, income is lower and households will increase labor supply to smooth income (i.e., the income effect) (Kochar, 1999; Rose, 2001). Do households with no or small adverse shocks increase labor supply to augment mutual insurance for helping others? In this paper, I test this resource-augmentation effect, which researchers have not yet explored, though Rosenzweig (2001) emphasizes the connection between self-insurance and mutual 
insurance as a future research agenda. The resource-augmentation effect broadens the role of the ex post labor supply as it is linked with risk sharing.

My conjecture is that whether the income effect or the resource-augmentation effect works depends on risk-return relationships of labor activities, because donors can take more high-risk, high-return options than recipients can. Most previous works on natural insurance examine wood and non-timber forest products (NTFPs) in forest-rich environments. As an exception, Takasaki et al. (2004; 2010) reveal that in the lowland Amazon, where both forest and riverine resources are rich, people more commonly resort to riverine fishing than NTFP gathering to cope with flood damage. Using original survey data, I compare forest and marine resources in the Pacific Islands, where the latter is much richer than the former. Although NTFP gathering offers very low returns to labor with almost no risk, people can make value-added handicrafts from NTFPs (the insurance role of handicrafts has received very little attention in previous works); coastal fishing is a high-risk, high-return activity. Hence, marine resources match mutual insurance better than forest resources. The analysis confirms that although the income effect works in both fishing and handicraft selling against crop damage caused by a tropical cyclone, the resource-augmentation effect works in only fishing against housing damage. I discuss how these distinct patterns of using commons as insurance are explained by distinct forms of risk sharing against these two shocks.

A better understanding of natural insurance's role in small island states, whose environments are highly vulnerable and economies heavily rely on foreign aid (Bertram, 1986), is critically important for successful resource management and safety-net policy. Some researchers criticize the deterioration of islanders' indigenous mechanisms in 
coping with cyclones because of their increasing dependency on emergency aid (e.g., Campbell, 1984). Contrary to extensive anthropological studies, economic studies based on household survey data are almost nonexistent in the Pacific region.

The rest of the paper is organized as follows. Section 2 describes the study area, the cyclone, and labor activities before and after the cyclone. Section 3 develops empirical strategies to test the income and resource-augmentation effects, which is followed by the results in Section 4 and discussion in Section 5. The last section concludes.

\section{STUDY AREA, CYCLONE, AND LABOR ACTIVITIES}

(a) Study area and data

Tropical cyclones are the largest natural disaster in Pacific island states. On January 13, 2003, Cyclone Ami swept over the northern and eastern regions of the Fiji Islands; Ami was the only cyclone in the northern region from 1991 through 2005 (McKenzie et al., 2005). Nine native Fijian villages on the coast in the northern region, with distinct environmental and economic conditions, were intentionally chosen for the survey. Six and three villages, respectively, are located on Vanua Levu and Taveuni Islands, the second- and third-largest islands in the country, which significantly lag behind the largest island, Viti Levu, where the state capital, two international airports, and most tourism businesses are situated. After being stratified for each of the selected villages by kin group, households were randomly sampled in each stratum $(\mathrm{n}=374)$; the analyses of this paper are conducted for 332 households with complete data. ${ }^{1}$

Household interviews were conducted between late August and early November 2003. Enumerators visited each household once within this time frame and inquired about 
production, income, assets, demographics, cyclone damage, and relief; neither consumption nor labor transfer data were collected. As such, like other post-disaster surveys (e.g., Morris et al., 2002), the survey collected pre- and post-cyclone information retrospectively (I will discuss retrospective errors in Section 3).

(b) Cyclone damage, housing rehabilitation, and relief

The total cyclone damage across the country is estimated at F\$104 million, of which housing damage is $\mathrm{F} \$ 22$ million and crop damage is $\mathrm{F} \$ 40$ million (1 Fiji dollar = US\$.60) (National Disaster Management Office, 2003). All nine sample villages experienced damage to their structures and facilities, and housing damage and crop damage are the two major damages individual households experienced. According to respondents' subjective assessments, the cyclone damaged 53\% of residents' houses: $8 \%$ were completely destroyed and $45 \%$ were partially damaged (see Table 1). I label households with damaged and undamaged housing victims and non-victims, respectively. Almost all households engaged in cropping (and fishing), and 86\% experienced crop damage. The mean value of damaged crops was F\$34 per adult equivalent, which was $57 \%$ of the mean monthly pre-cyclone crop income (crop damage was calculated based on the quantity damaged for each major crop, as reported by respondents).

\{Table 1 here

Variance of the household-level housing- and crop-damage measures is decomposed into village, kin-group (village sub-group), and household levels by allowing for village- or group-level means. In practice, the village-level variance (percent of total variance) is the R-squared of a regression on a full set of village dummies; the group-level variance is the R-squared of a regression on a full set of group dummies, 
minus the village-level variance. The contribution of the village-level variance to total variance is small (less than 7\%), that of the group-level variance is considerable (1016\%), and most variance exists at the household level (77-85\%). As such, in the regression analyses below, I focus on household-level idiosyncratic shock and grouplevel covariate shock. ${ }^{2}$

Housing damage and crop damage are not correlated with each other. Correlations of housing damage with crop damage and crop-damage value are .001 and -.0145, respectively, and correlations of the proportion of damaged housing in the kin group with the proportion of households with damaged crops in the group and the group mean of crop-damage value are -,068 and .022, respectively; none of these results are statistically significant (the comparison of non-victims and victims in Table 1 shows comparable results).

Thirty-seven percent of victims became refugees who stayed in others' residences in the same village (according to a village survey conducted in each sample village, permanent migration was nonexistent). About half of the refugees lived with households in the same kin group; that is, the kin group served as a risk-sharing group. Non-victims helped victims rehabilitate their housing, though with no data on across-household labor transfers, I cannot tell how people actually helped each other. At the same time, villagers contributed to rehabilitating damaged village facilities. Using the same Fijian data, Takasaki (forthcoming) shows that contributions of communal labor (mainly male) are smaller among households with damaged housing and with greater crop damage; that is, communal labor corresponding to village-level covariate shock involves risk-sharing arrangements against household-level idiosyncratic shocks. At the time of interviews, 
refugees were almost nonexistent and about two thirds of victims had completed housing rehabilitation: 9\% had built a new house and 55\% had completed repairs. As the government provisioned most construction materials more than one year after the cyclone, these housing rehabilitations were accomplished by people’s mutual help.

The Red Cross, other nongovernmental organizations, and the government delivered relief. Emergency food aid was the largest form of relief in the region. Almost all sample households received some food aid by April and they received about 10 days worth of food per month, on average, until September; that is, an average household could rely on aid to cover about one third of its food consumption (Takasaki, forthcoming). ${ }^{3}$ The value of the total 90-day food ration over nine months, F\$156 per capita, is 4.5 times the average crop damage per adult equivalent. In contrast, primitive tarpaulins - to be used as emergency shelters and for temporary housing repair - were provisioned to only $12 \%$ of households (mostly victims) by June.

(c) Labor activities

Panel A of Table 2 compares incomes earned from labor activities before and after the cyclone. Cropping and fishing accounted for 54\% and 29\%, respectively, of total income before the cyclone. ${ }^{4}$ Distinct from housing rehabilitation, households individually rehabilitated cropping by collecting harvestable damaged crops, cleaning fields, and planting seeds. People planted fast-growing crops (like sweet potato) after seeds were provisioned as part of the relief, and the harvest had already started before the interviews. Recovery was still incomplete: The mean post-cyclone crop income was about 40\% lower than the pre-cyclone level. Fishing income also decreased significantly after the cyclone. 
\{Table 2 here $\}$

The collection of NTFPs, such as wild fruits (excluding those used for handicraft making), and handicraft selling (in local markets and small resort hotels for tourists) contributed negligibly to total income before the cyclone. ${ }^{5}$ These two minor activities were almost nonexistent throughout the previous year in three of the nine sample villages. Panel B of Table 2 reports participation in and revenues from these two activities in the remaining six participant villages $(n=223)$ by quarter - pre-cyclone period 1 (OctoberDecember 2002) and post-cyclone periods 2-4 (January-March, April-June, and JulySeptember 2003, respectively). In period 2 right after the cyclone, households abandoned NTFP gathering. Most NTFPs are seasonal, ${ }^{6}$ but seasonality only partly explains this pattern; the deteriorated access to gathering sites caused by downed trees and debris precluded gathering in some but not all locations. The most likely reason for this was to free labor for other coping activities under a state of emergency. Gathering recovered in periods 3 and 4, while participation was still much lower than in period 1. Participation in and revenues from handicraft selling did not change much from period 1 to period 2 but increased later. This pattern matches the recovery of tourists' demand. These results suggest that after the emergency period, households shifted labor from risky fishing and NTFP gathering with low returns to production of value-added handicrafts. ${ }^{7}$

(d) Comparison of victims and non-victims

Victims and non-victims did not significantly differ from each other in their precyclone incomes, asset holdings (land and fishing capital), and other household characteristics (Panel A of Table 2); the only exception is that households with a younger head were more likely to experience housing damage. This is because they relied more on 
inferior construction materials (thatched walls or ground floors covered by a mat, cf. wood walls and floors, Takasaki, forthcoming). Housing damage could also be related to the micro location of housing within each village, the data of which are lacking. Put differently, pre-cyclone labor activities, asset holdings, and most other household characteristics are not correlated with such housing quality. At the same time, nonvictims earned greater total income after the cyclone than victims, especially in fishing (the difference is significant at only a $12 \%$ significance level). Thus, ex post fishing adjustments were somewhat different between victims and non-victims.

\section{ANALYSES}

This section develops empirical strategies to test the income effect and the resource-augmentation effect, followed by discussions of estimation strategies, covariates, and measurement errors.

\section{(a) Income effect}

The income effect suggests that a household increases labor supply in response to adverse shocks. Rose (2001) offers a theoretical framework for household labor-supply decisions in response to a covariate shock to farm production (regional rainfall). Adding an idiosyncratic shock to her model yields the ex post labor-supply equation

$$
L=L(z, W, X, M)
$$

where $L$ is labor supply; $z$ and $W$, respectively, are adverse household-level idiosyncratic shock and village-level covariate shock; and $X$ and $M$, respectively, are household- and village-level factors that affect returns to labor, such as productive assets and market prices. The estimating equation is:

$$
L_{i t}=\beta_{0}+\beta_{1} z_{i t}+\gamma X_{i t}+V_{v t}+u_{i}+e_{i t}
$$


where $i, v$, and $t$ stand for household, village, and time, respectively; $V_{v t}$ is time-varying village dummies, which capture all village-level factors, such as village-level covariate shock and seasonality (see below for more discussion); $u_{i}$ is unobservable household heterogeneity; and $e_{i t}$ is a time-variant error term that is individually and independently distributed. Previous works on ex post labor supply and natural insurance largely employ equation (1). The income effect against own household-level shock (self-insurance) is captured by positive $\beta_{1}$. I extend equation (1) to

$$
L_{i t}=\beta_{0}+\beta_{1} z_{i t}+\beta_{2} w_{g t}+\gamma X_{i t}+V_{v t}+u_{i}+e_{i t}
$$

where $w_{g t}$ is group-level covariate shock of a group $g$ (kin group in the Fijian case).

Risk sharing among group members lowers the demand for income smoothing through self-insurance. In the extreme case of full risk sharing, the labor supply is unresponsive to household-level idiosyncratic shock, while the income effect can work against uninsured group-level covariate shock. As the full risk-sharing model captures consumption smoothing against idiosyncratic shock after households earn ex post labor income, reduced-form equations (1) and (2) capture the household-labor response to idiosyncratic shock after it is weakened by risk sharing. In this way, unobservable welfare weights used in risk sharing affect household labor-supply decisions. Hence, to identify the income effect against idiosyncratic shock, researchers need to control for household heterogeneity $u_{i}$ using fixed-effects estimators; this is true for any idiosyncratic shocks, such as sickness. ${ }^{8}$

(b) Resource-augmentation effect

The resource-augmentation effect suggests that additional labor income increases shared resources. To clearly illustrate my empirical strategy to test for the resource- 
augmentation effect, which consists of two steps, consider a hypothetical situation where an idiosyncratic shock - exogenous as a determinant of labor supply - is a dummy variable that largely distinguishes recipients $(\mathrm{R})$ and donors $(\mathrm{D})$ of private transfers among group members. The group mean of this dummy, the proportion of households with the shock (i.e., recipients) in the group, measures group-level covariate shock. The first step examines whether donors with no shock increase labor supply in response to the shocks experienced by recipients in the same group. This is captured by the positive coefficient of this group-level shock - measured in the whole sample - in equation (2) run for the donor sample (i.e., $\beta_{2}^{D}>0$ ). In the whole sample, then, the positive coefficient of the group-level shock $\left(\beta_{2}>0\right)$ can be a result of either the income effect or the resource-augmentation effect, or both.

Positive $\beta^{D}{ }_{2}$ does not necessarily mean that donors augment transfers to recipients. With a lack of across-household labor-transfer data in Fiji, the second step examines how the ex post labor supply is related to housing rehabilitation (if consumption data were available, the same analysis could be done about consumption smoothing). The resourceaugmentation effect suggests that the greater ex post labor supply among donors, the better smoothing (rehabilitation) among recipients. In particular, risk sharing depends on donors' resources per recipient that can be shared within groups. I thus conduct a grouplevel correlation analysis to test the following: (1) Housing rehabilitation is positively correlated with the total labor supply of donors, but not recipients, in the group (hypothesis 1); (2) Housing rehabilitation is positively correlated with the labor supply of donors per recipient in the group (hypothesis 2); (3) This correlation of donors' labor supply per recipient is greater than that of their group mean labor supply (hypothesis 3). 
In practice, the clear division of donors and recipients in risk sharing against a particular idiosyncratic shock is very unlikely, because it is affected by other shocks and factors (like wealth). What researchers can do is to conduct the sub-sample analysis on each major idiosyncratic shock (housing damage and crop damage in the Fijian case). That $\beta_{2}$ is positive and hypotheses $1-3$ hold for housing damage is good evidence that non-victims and victims are main donors and recipients, respectively, in the risk sharing among group members for housing rehabilitation.

My conjecture is that the resource-augmentation effect is stronger in marineresource use than in forest-resource use, because of their distinct risk-return relationships. I analyze fishing and handicraft selling separately (NTFP gathering yields regression results with very weak overall significance, probably because of very uncommon participation after the cyclone).

\section{(c) Estimation strategies}

As many households do not participate in handicraft selling (Panel B of Table 2), I employ the trimmed least-squares estimator developed by Honoré (1992) to control for unobservable household heterogeneity $u_{i}$ with a censored dependent variable. Another advantage of this fixed-effects model, which has not been used in previous works on the ex post labor supply, is that it is robust to heteroskedasticity and non-normality, which are other potential sources of bias in random-effects Tobit estimates. I employ the firstdifference estimator for fishing, participation in which is almost universal.

When do people rely on natural insurance against the cyclone, during the emergency period or after? To answer this question, I conduct two-period analyses of handicraft selling separately for periods 1 and 2, periods 1 and 3, and periods 1 and 4 . In 
the latter two, labor input in period 3 or 4 is connected with the shocks experienced in period 2. This is a standard practice in analyzing annual survey data that lack information over time within the year. A potential problem is that coping behaviors in the previous post-cyclone period(s) correlated with shocks may affect decisions in the subsequent period as an “unobservable” time-variant factor. I repeat the analyses constructing dependent variables over periods $2-3$ or periods $2-4$, finding very similar results. In the two-period model for fishing, the ex post data are measured at the time of interviews.

With a lack of time-allocation information, I use revenues as a proxy for labor inputs (revenues are a better proxy than incomes). The fixed-effects and first-difference estimators control for any systematic difference between revenues and labor inputs caused by unobservable, time-invariant factors, such as skills and resource stocks (in the Fijian data, fishing capital is also time-invariant, as discussed shortly); village-time dummies control for market prices, which determine revenues. The group-level correlation analysis to test hypotheses $1-3$ is conducted for revenues and incomes (incomes better capture resources that can be shared).

(d) Covariates

Household-level shock $z_{i t}$ consists of two dummies for partial housing damage and complete damage and the value of crop damage per adult equivalent (log). Household crop damage is endogenous, because unobservable household and village characteristics, such as land quality, farming skills, market conditions, and environmental conditions, which affect household pre-cyclone cropping decisions and thus crop damage, can be correlated with its ex post labor-supply decisions. In the Fiji data, most of these unobservable factors are fixed effects $u_{i}$, which can be controlled for. Housing quality 
(construction materials and micro location), which affects housing damage, is also fixed effects. In equation (2), group-level shock $w_{g t}$ is captured by the group means of the three household-level shocks. The group-mean estimates should be reasonably accurate because, on average, the sample includes about $70 \%$ of households in each stratum defined by kin group.

Potential selection bias in the sub-sample analysis on housing damage is unlikely to be a major concern, because victims and non-victims differ from each other only in their housing quality, as discussed above. In the sub-sample analysis on crop damage, I consider various breakpoints in crop-damage value (the analysis on a dummy for crop damage is infeasible because most households experienced the damage). This analysis is at best very preliminary, because endogenous crop-damage value can cause significant selection bias. Still, it can highlight the potential contrast to housing damage.

Village-time dummies $V_{v t}$ capture all village-level factors: village-level shocks to housing and crops (which are shown to be small above), damage to village structures and facilities, village-level seasonality (e.g., change in resource stock), and relief received by the village. Though, for example, relief allocations across villages might be correlated with unobservable village-level factors that determine returns to labor activities, such factors are fully controlled for by the village-time dummies. Relief received by individual households is not included as an explanatory variable, because it is endogenously determined as part of private risk sharing within villages (Dercon and Krishnan, 2005; Takasaki, forthcoming). A time dummy controls for region-level covariate shocks and seasonality, and other common events or trends. In the Fijian data, household-level factors that affect returns to labor $X_{i t}$, such as productive assets and demographic factors, 
are fixed effects. In particular, fishing capital and land holdings hardly changed in the previous year (no land was lost because of the cyclone).

\section{(e) Measurement errors}

Special attention needs to be given to measurement errors in the retrospective data. First of all, errors in the measure of housing damage are minimal, because relief officers used the same categories for their damage assessments (the damage status of each house was common knowledge among villagers). Measurement errors in the value of crop damage can be considerable and systematic. I repeated the analyses using the cropdamage dummy, the errors of which should be minimal, finding qualitatively the same results.

Respondents’ memory inaccuracy in early periods may have caused the evolution of production found above. Such memory inaccuracy should be small for participation, because the very minor activity of NTFP gathering was much less common in periods 3 and 4 than in period 1; though measurement errors in the timing of handicraft production may be systematically correlated with household-level shocks, similar estimation results using combined post-cyclone periods discussed above suggest that such errors are unlikely to be a major concern.

Although respondents could well recall the production of handicrafts because they are culturally and socially important among Fijians (Turner, 1987), handicraft and fishing revenues may contain significant errors. The time dummy and village-time dummies control for common memory inaccuracy, but the correlation of errors in pre-cyclone revenues with household-level shocks can cause significant bias. There is no way to control for this potential bias. A positive (negative) correlation - households with larger 
shocks tend to report higher (lower) pre-cyclone revenues than actual revenues - causes upward (downward) bias. Thus, unless the correlation is positive and large, estimated positive $\beta_{1}$ (income effect) should be qualitatively robust. In contrast, in the sub-sample analysis for non-victims (with no damaged housing), such potential bias caused by housing damage is irrelevant. Hence, estimated positive $\beta^{D}{ }_{2}$ for victims' housing damage in the group (resource-augmentation effect) should be robust. The group-level correlation analysis using data at the time of interviews should not involve major recall errors.

\section{RESULTS}

The first-difference estimates of determinants of log fishing revenues per adult equivalent per month are reported in Table 3, where robust standard errors are reported and standard errors are clustered by kin group in equation (2). The first two columns show results for the whole sample. Households intensify fishing against their own crop damage, but not housing damage, in equation (1) (i.e., $\beta_{1}>0$ ); in equation (2), the crop damage loses its statistical significance, but when standard errors are not clustered by group, it is significant at the $5 \%$ level (results not shown). Though the marginal effect of crop-damage value is small (.7\% for a $10 \%$ increase in damage), that of the crop-damage dummy is about $28 \%$ (results not shown). Hence, the income effect of fishing works against own crop damage. At the same time, households in a kin group with more complete housing damage intensify fishing, though group-level partial housing damage and crop damage exhibit no significant impacts.

\section{\{Table 3 here $\}$}

The results of sub-sample analyses for non-victims and victims are reported in columns (3)-(4) and columns (5)-(6), respectively. Group-level complete and partial 
housing damage, but not crop damage, positively influences non-victims only (i.e., $\beta_{2}^{D}>$ 0). Non-victims intensify fishing against victims’ housing damage in the group; the marginal effect of complete damage is greater than that of partial damage ( $14 \%$ and $8 \%$, respectively, for an additional victim in an average kin group with 10 member households). This gives rise to the distinct post-cyclone fishing incomes between nonvictims and victims found above. In contrast, no group-level shocks show a significant impact in the sub-sample analysis on crop damage (columns 7-10) (the breakpoint is the median of crop-damage value, F\$18.9; using other percentiles as a breakpoint yields qualitatively the same results).

The results of the group-level correlation analysis - weighted by kin-group size of fishing revenues are reported in column (1) of Table 4, where housing rehabilitation is measured by the proportion of housing rehabilitated - new housing built or repair completed - among victims in kin groups (groups with no victims are dropped). Housing rehabilitation is positively correlated with non-victims' total fishing revenues and their revenues per victim in the group, but not their group-mean revenues; that is, hypotheses 1-3 all strongly hold. The analysis of fishing incomes yields almost the same results (results not shown). Overall then, the resource-augmentation effect works against housing damage: Non-victims (as main donors) intensify fishing to help the rehabilitation of victims (as main recipients) in kin groups. Moreover, the resource-augmentation effect corresponds to the severity of housing damage. ${ }^{9}$

\{Table 4 here

Trimmed least-squares estimates for log handicraft sales per adult equivalent per month, for the whole sample in six handicraft villages, are reported in Table 5 (the 
sample size is too small for a sub-sample analysis). Households with greater own crop damage, not housing damage, sell more handicrafts (i.e., $\beta_{1}>0$ ) in period 3 ; at the same time, no group-level shocks exhibit significant impacts. The group-level correlation analysis for six handicraft villages in periods 2-4 shows that hypotheses 1-3 do not hold at all (column 2 of Table 4). ${ }^{10}$ Hence, the income effect of handicraft selling works against crop damage, though the resource-augmentation effect is nonexistent.

\{Table 5 here

\section{DISCUSSION}

Why does fishing's resource-augmentation effect work for housing damage, but not crop damage? Why does the income effect work for crop damage, but not housing damage? I argue that risk sharing against these two shocks works differently for two reasons. First, donors and recipients in risk sharing for housing rehabilitation are much more sharply distinguished from each other than those for consumption smoothing against crop damage. This is because depending on housing quality, which is very observable among kin-group members, housing damage divided households almost equally into victims and non-victims, and thus there is approximately one non-victim (potential donor) for each victim (potential recipient), on average. In contrast, most households experienced crop damage and its magnitude was determined by their precyclone cropping decisions, and cropping efforts are less observable than housing quality. These contrasts of housing damage and crop damage are reflected in earlier descriptive findings on mutual help and its absence - co-residence for refugees among kin members, risk-sharing arrangements in communal labor, and the absence of labor sharing in crop rehabilitation. 
Second, compared to generous emergency food aid, which must have greatly helped households’ consumption smoothing against crop damage, very limited relief was available for housing rehabilitation - limited tarpaulins and no construction materials. Attanasio and Rios-Rull (2000) theoretically demonstrate that public transfer crowds out private transfer in risk sharing, because in the risk-sharing arrangement with limited enforceability, public transfer, which increases the value of autarky relative to the value of staying in the contract, reduces the degree of risk sharing (they obtain supporting evidence in Mexico’s PROGRESA program, and Dercon and Krishnan, 2005 find similar results for food aid in rural Ethiopia). If cyclone relief crowds out risk sharing against cyclone shocks in Fiji, it should be much greater for that against crop damage than housing damage (with only nine sample villages, examining potential crowding-out of informal risk sharing caused by cyclone relief is infeasible). As a result, people rely more on self-insurance against crop damage and mutual insurance against housing damage.

Why does handicraft's income effect work in period 3 only? I argue that the demand for self-insurance against crop damage changes over time. The income effect was weak under emergency, because people could collect harvestable damaged crops and needed quick help through mutual insurance (co-residence for refugees and emergency repair of damaged housing). The demand for self-insurance was augmented in the lean period 3, when households were still waiting to harvest rehabilitated crops. The demand decreased in period 4, when people started to harvest rehabilitated crops and received a good cumulative amount of food aid; an increase in handicraft sales at that time is mainly explained by seasonality, in particular, the recovery of tourists’ demand. 


\section{CONCLUSION}

Poor people rely on local commons not only for self-insurance, as commonly found, but also for mutual insurance. Their choices depend on resources, which involve distinct risk-return relationships, and shocks, against which informal risk sharing can work differently. This paper demonstrated that this conjecture holds among cyclone victims in the Pacific Islands. On one hand, households increase coastal fishing and handicraft selling to smooth income against own crop damage. On the other hand, households with undamaged housing intensify fishing to help other kin-group members with damaged housing. Both responses occur after the emergency period; during the emergency period, people abandon forest-product gathering.

Hence, local commons can play a broader role as a safety net than normally thought for two reasons. First, even if resource use is too risky for self-insurance (e.g., fishing), it is not too risky for donors to augment mutual insurance, especially when mutual insurance works strongly (e.g., housing rehabilitation). Second, the value-adding process (e.g., handicraft making) strengthens the self-insurance role of poor local commons. This is important when mutual insurance works weakly (e.g., crop damage). Under the emergency situation right after a disaster, however, people do not resort to natural self-insurance but instead rely on private risk sharing and disaster relief, if any (whether commons help mutual insurance at that time is an unanswered question).

These findings suggest the strong demand for integrating community-based resource management and broad safety-net policies. As seen in Fiji, however, different management groups may correspond to different natural resources (e.g., forest vs. sea), and management groups may not match risk-sharing groups. More research on the link of 
local resource use and management with informal risk sharing is needed. In some locales like Fiji, development of handicraft enterprises and markets is promising for both income enhancement and better safety nets.

\section{Notes}

${ }^{1}$ Fijians are divided almost equally into native Fijians and Indo-Fijians, and the study focuses on the former. The hierarchical kin structure of native Fijians is well known among anthropologists: The bottom is tokatoka, followed by mataqali, yavusa, and vanua, and each native Fijian belongs to one tokatoka, which belongs to one mataqali, and so forth (Ravuvu, 1983). Vanua ranges over several villages, roughly matching a district; there is one or a few yavusa in each village. In each sample village, households were stratified by tokatoka, the smallest kin-group unit. Households were also stratified for each tokatoka, depending on whether they hold leadership status or major assets (such as a shop), or not. This paper focuses on tokatoka as a kin group. To better capture grouplevel factors, several tokatoka consisting of only one household are dropped. The sample for the analyses includes 15 yavusa, 36 mataqali, and 49 tokatoka (all nine villages contain more than one tokatoka and mataqali).

${ }^{2}$ With only nine villages in the sample, a statistical analysis of village-level covariate shocks is infeasible; at the same time, as the survey covers only the northern region in the small island state, variations in village-level shocks in the study area are very limited. To analyze village-level covariate shocks, data covering a large number of villages with much richer spatial variations - ideally including villages with no cyclone damage - are needed (in Fiji, such data should be based on a national sample covering all regions). If historical covariate shock data with rich regional variations were also available, ex ante 
labor-supply decisions against risk could be explored. Using such data in Guatemala, Pörtner (2008) examines how hurricane risks and shocks affect fertility and education. This paper focuses on ex post labor-supply decisions.

${ }^{3}$ Because respondents found it difficult to specify the monetary value of food aid they received, they instead were asked the quantity, measured in the number of days it would have taken to consume the food in normal periods (not actual duration). The cost of the food ration is estimated at F\$1.73 per person per day (National Disaster Management Office, 2003).

${ }^{4}$ Households employ traditional cropping practices (using no mechanized equipment or animal traction and limited purchased inputs) to produce mainly taro, cassava, coconut, and kava. Households engage in subsistence fishing using lines and hooks, simple spear guns, or rudimentary nets, and more commercially oriented fishermen use boats and engines, along with more valuable nets. Rural land is communally owned by mataqali, and is privately used, and by law it cannot be sold (communal land consists of about 83\% of the country's total land). Customary rights for coastal fishing are held by vanua or several yavusa, which often consist of several villages. In some fishing areas, regulations such as the bans on Sunday fishing and gill nets exist (no fishing regulations were altered after the cyclone). Enumerators asked questions about the production of major crops and the catch of finfish and other marine products in the past one month, and then monthly production a year before, in comparison with the latest figures (the contribution of other marine products to total income was much smaller than that of finfish). 
${ }^{5}$ NTFPs on communal land are open access not only to mataqali members but also to all villagers, and forest extraction is unregulated. The three most important handicrafts are famous Fijian mats, voivoi (made of screw pine, Pandanus thurstonii), finer mats, kuta (made of soft sedge, Eleocharis dulcis), and bark cloths, tapa (made of paper mulberry, Broussnetia papyrifera). These handicrafts are made exclusively by women and are extensively used for ceremonial gifts (Turner, 1987); some craftswomen sell their products. Enumerators asked about NTFP gathering and handicraft production in each month over the past one year.

${ }^{6}$ In the village survey, respondents were asked to list major NTFPs, finfish species, and other marine products harvested by villagers and whether or not each product is seasonal. Among all products listed, 91\%, 17\%, and 77\% of NTFPs (excluding firewood), finfish species, and other marine products, respectively, are seasonal (unweighted).

${ }^{7}$ Potential coping activities other than private transfers played very minor roles. Casual wage labor, a focus of previous studies on the ex post labor supply, was very rare, contributing negligibly to the total income (Panel A of Table 2). Livestock selling also contributed little. The disposition of fishing capital and the transfer of usufruct of land after the cyclone were nonexistent. Formal credits and insurance were nonexistent. ${ }^{8}$ Numerous works test the full risk-sharing hypothesis using the equation

$$
c_{i t}=\alpha_{0}+\alpha_{1} z_{i t}+V_{v t}+u_{i}+v_{i t}
$$

where $c_{i t}$ is household consumption (Cochrane, 1991; Mace, 1991; Townsend, 1994). The null hypothesis is that household consumption is unaffected by idiosyncratic shock, as households efficiently share available resources that are altered only by covariate shock, 
i.e., $\alpha_{1}=0$. As unobservable welfare weights used in risk sharing are correlated with idiosyncratic shock, fixed-effects estimators are required to obtain unbiased estimates. To examine risk sharing within groups other than villages, such as castes (Morduch, 2005) and household networks (De Weerdt and Dercon, 2006; Fafchamps and Lund, 2003), researchers have employed the following extended model

$$
c_{i t}=\alpha_{0}+\alpha_{1} z_{i t}+\alpha_{2} w_{g t}+V_{v t}+u_{i}+v_{i t} .
$$

Although this extension is the same as the extension of equation (1) to (2), the interpretation of group-level shock is different from that in (2), which is offered shortly: If risk is shared at the village level and not group, the addition of group-level shock is redundant, because village-level shock is already controlled for; its significant impact on consumption means that risk is shared among group members.

${ }^{9}$ I repeated the analyses using mataqali as alternative kin group, finding very similar results. Hence, the resource-augmentation effect works mostly within tokatoka, a subgroup of mataqali, suggesting that mutual insurance is mainly available among close kin members. I also extended the regression analyses as follows. First, individual returns to fishing should vary across households, depending on their fishing-capital holdings (cf. forest-resource use). To see whether the income effect of ex post fishing depends on capital holdings, as found by Takasaki et al. (2010), I add interaction terms of householdlevel shocks with pre-cyclone individual fishing capital holdings per adult equivalent (log) (recall that capital holdings are essentially fixed effects in the Fijian data). Second, as in other developing regions, share fishing is relatively common in the study area households that are poor in fishing capital work with others with large holdings in 
exchange for a share of the catch (Platteau and Nugent, 1992). To see whether the resource-augmentation effect depends on group members’ capital holdings, I add interaction terms of group-level shocks with the group mean of individual capital holdings. Third, inequalities are often considered a potential determinant of the use of commons, and mixed results of their effects are found in the literature (e.g., Alix-Garcia, 2008; Baland and Platteau, 1997). Previous work has not explored how inequalities influence the insurance role of commons. I add interaction terms of group-level shocks with the coefficient of variations - standard deviations divided by means - of individual capital holdings in the group. None of these interaction terms are statistically significant and none of the remaining results change significantly (results not shown). Hence, the income effect and the resource-augmentation effect of fishing are neutral to fishing capital and its within-group inequality.

${ }^{10}$ Mean handicraft revenues earned by victims are negatively correlated with housing rehabilitation. This probably suggests that as victims augment handicraft selling, they contribute less to risk sharing and thus receive less help from non-victims. This is buttressed by the negative correlation with victims' revenues per non-victim in the group. This indicates a potential tradeoff involved in ex post labor-supply decisions, the better exploration of which requires an examination of consumption smoothing. 


\section{References}

Alix-Garcia, J. (2008). An Exploration of the Positive Effect of Inequality on Common Property Forests. Journal of Development Economics 87(1), 92-105.

Angelsen, A., S. Wunder (2003). Exploring the forest-poverty link: key concepts, issues and research implications. CIFOR Occasional Paper No. 40, Bogor: CIFOR.

Attanasio, O., J.-V. Rios-Rull (2000). Consumption Smoothing in Island Economies: Can Public Insurance Reduce Welfare? European Economic Review 44(7), 1225-58.

Baland, J.-M., P. Francois (2005). Commons as Insurance and the Welfare Impact of Privatization. Journal of Public Economics 89(2-3), 211-31.

Baland, J.-M., J.-P. Platteau (1997). Wealth inequality and efficiency in the commons: part I: the unregulated case. Oxford Economic Papers 49, 451-482.

Bertram, G. (1986). Sustainable development in Pacific microeconomies. World Development 14(7), 809-822.

Campbell, J. R. (1984). Dealing With Disaster: Hurricane Response in Fiji. Honolulu: Pacific Islands Development Program, East-West Centre.

Cochrane, J. H. (1991). A simple test of consumption insurance. Journal of Political Economy 99(5), 957-976.

De Weerdt, J., S. Dercon (2006). Risk-Sharing Networks and Insurance Against Illness. Journal of Development Economics 81(2), 337-56.

Delacote, P. (2007). Agricultural expansion, forest products as safety nets, and deforestation. Environment and Development Economics 12, 235-249.

Dercon, S., P. Krishnan (2005). Food Aid and Informal Insurance. In S. Dercon (Ed.), Insurance Against Poverty. Oxford and New York: Oxford University Press. 
Fafchamps, M., S. Lund (2003). Risk-sharing networks in rural Philippines. Journal of Development Economics 71(2), 261-287.

Fisher, M., G. Shively (2005). Can Income Programs Reduce Tropical Forest Pressure? Income Shocks and Forest Use in Malawi. World Development 33(7), 1115-28. Honoré, B. E. (1992). Trimmed LAD and Least Squares Estimation of Truncated and Censored Regression Models with Fixed Effects. Econometrica 60(3), 533-65.

Hunter, L., W. Twine, A. Johnson (2007). "Locusts are now our beef": Adult mortality and household dietary use of local environmental resources rural South Africa. Scandinavian Journal of Public Health 35(Suppl 69), 165-174.

Jodha, N. S. (1986). Common property resources and rural poor in dry region of India. Economic and Political Weekly 21(27), 1169-1181.

Kochar, A. (1999). Smoothing consumption by smoothing income: hours-of-work responses to idiosyncratic agricultural shocks in rural India. Review of Economics and Statistics 81(1), 50-61.

Mace, B. J. (1991). Full insurance in the presence of aggregate uncertainty. Journal of Political Economy 99(5), 928-956.

McKenzie, E., B. Prasad, A. Kaloumaira (2005). Economic impact of natural disasters on development in the Pacific: Volume 1 Research report. Suva: The University of the South Pacific.

McSweeney, K. (2005). Natural Insurance, Forest Access, and Compounded Misfortune: Forest Resources in Smallholder Coping Strategies before and after Hurricane Mitch, Northeastern Honduras. World Development 33(9), 1453-71. 
Morduch, J. (2005). Consumption Smoothing across Space: Testing Theories of RiskSharing in the ICRISAT Study Region of South India. In S. Dercon (Ed.), Insurance Against Poverty. Oxford and New York: Oxford University Press.

Morris, S. S., O. Neidecker-Gonzales, C. Carletto, M. Munguia, J. M. Medina, W. Wodon (2002). Hurricane Mitch and the Livelihoods of the Rural Poor in Honduras. World Development 30(1), 49-60.

National Disaster Management Office (2003). Report on Tropical Cyclone Ami. Suva: Ministry of Regional Development, Fiji.

Pattanayak, S., E. Sills (2001). Do tropical forests provide natural insurance? The microeconomics of non-timber forest product collection in the Brazilian Amazon. Land Economics 77(4), 595-612.

Platteau, J. P., J. Nugent (1992). Share contracts and their rationale: lessons from marine fishing. Journal of Development Studies 28(3), 386-422.

Pörtner, C. (2008). Gone With the Wind? Hurricane Risk, Fertility and Education. Department of Economics Working Papers UWEC-2006-19-R, Seattle: University of Washington

Ravuvu, A. (1983). Vaka I Taukei: The Fijian Way of Life. Suva: Institute of Pacific Studies.

Rose, E. (2001). Ex ante and ex post labor supply response to risk in a low-income area. Journal of Development Economics 64(2), 371-388.

Rosenzweig, M. R. (2001). Savings behavior in low-income countries. Oxford Review of Economic Policy 17(1), 40-54. 
Takasaki, Y. (forthcoming). Targeting cyclone relief within the village: kinship, sharing, and capture. Economic Development and Cultural Change.

Takasaki, Y., B. L. Barham, O. T. Coomes (2004). Risk coping strategies in tropical forests: floods, illness, and resource extraction. Environmental and Development Economics 9(2), 203-224.

Takasaki, Y., B. L. Barham, O. T. Coomes (2010). Smoothing income against crop flood losses in Amazonia: rain forest or rivers as a safety net? Review of Development Economics 14(1), 48-63.

Townsend, R. M. (1994). Risk and insurance in village India. Econometrica 62(3), 539591.

Turner, J. W. (1987). Blesses to give and receive: ceremonial exchange in Fiji. Ethnology 26(3), 209-219. 
Table 1. Cyclone damage by housing damage, variance decomposition of cyclone damage, and housing rehabilitation.

\begin{tabular}{|c|c|c|c|c|c|c|c|}
\hline & \multicolumn{3}{|c|}{ Household means $^{a}$} & \multirow{2}{*}{$\begin{array}{c}\text { Mean/ } \\
\text { prop. test } \\
(p-\text { value })^{b}\end{array}$} & \multicolumn{3}{|c|}{$\begin{array}{c}\text { Variance } \\
\text { decomposition }^{\mathrm{c}}\end{array}$} \\
\hline & $\begin{array}{c}\text { All } \\
(n=332)\end{array}$ & $\begin{array}{c}\text { Non-victims } \\
(n=155)\end{array}$ & $\begin{array}{l}\text { Victims } \\
(n=177)\end{array}$ & & Village & Group & $\begin{array}{l}\text { House- } \\
\text { hold }\end{array}$ \\
\hline \multicolumn{8}{|l|}{ Household-level shocks: } \\
\hline Housing damaged dummy & $0.53(0.50)$ & $0.00(0.00)$ & $1.00(0.00)$ & - & 6.6 & 16.1 & 77.3 \\
\hline Housing partially damaged dummy & $0.45(0.50)$ & $0.00(0.00)$ & $0.84(0.37)$ & - & 6.8 & 14.4 & 78.8 \\
\hline Housing completely damaged dummy & $0.08(0.28)$ & $0.00(0.00)$ & $0.16(0.37)$ & - & 1.6 & 13.8 & 84.7 \\
\hline Crop damaged dummy & $0.86(0.35)$ & $0.86(0.35)$ & $0.86(0.35)$ & 0.236 & 5.7 & 10.8 & 83.5 \\
\hline Crop damage per adult equivalent $(\mathrm{F} \$$ ) & $34.4(44.7)$ & $35.1(49.5)$ & $33.8(40.1)$ & 0.396 & 2.7 & 13.6 & 83.7 \\
\hline \multicolumn{8}{|l|}{ Group-level shocks: } \\
\hline Proportion of housing damaged in the kin group & $0.53(0.24)$ & $0.41(0.23)$ & $0.64(0.19)$ & 0.000 & & & \\
\hline Proportion of housing partially damaged in the kin group & $0.45(0.23)$ & $0.34(0.21)$ & $0.54(0.21)$ & 0.000 & & & \\
\hline Proportion of housing completely destroyed in the kin group & $0.08(0.11)$ & $0.07(0.10)$ & $0.10(0.12)$ & 0.125 & & & \\
\hline Proportion of crop damaged in the kin group & $0.86(0.14)$ & $0.86(0.14)$ & $0.85(0.14)$ & 0.730 & & & \\
\hline Kin-group mean of crop damage & $34.4(18.0)$ & $34.2(18.6)$ & $34.5(17.5)$ & 0.919 & & & \\
\hline \multicolumn{8}{|l|}{ Housing rehabilitation among victims $(n=170)$ : } \\
\hline Complete housing repair dummy & - & - & $0.55(0.50)$ & - & & & \\
\hline New housing construction dummy & - & - & $0.09(0.29)$ & - & & & \\
\hline
\end{tabular}

${ }^{a}$ Household means are shown along with standard deviations in parentheses.

${ }^{\mathrm{b}}$ Results with a $5 \%$ significance level are bolded.

${ }^{\mathrm{c}}$ These are percents of total variance. 
Table 2. Household labor activities and characteristics.

\begin{tabular}{|c|c|c|c|c|}
\hline Pre- and post-cyclone income and & $\begin{array}{c}\text { clone hou } \\
\text { All } \\
(n=332)\end{array}$ & $\begin{array}{l}\text { Id characteri } \\
\text { Non-victims } \\
(n=155)\end{array}$ & $\begin{array}{l}\text { tics by hol } \\
\text { Victims } \\
(n=177)\end{array}$ & $\begin{array}{c}\text { ing damage } \\
\text { Mean/ } \\
\text { prop. test } \\
\text { (p-value) }^{c}\end{array}$ \\
\hline \multicolumn{5}{|c|}{ Income per adult equivalent per month a year ago - pre-cyclone (F\$): } \\
\hline Cropping & $60.2(90.8)$ & $65.1(91.6)$ & $55.9(90.1)$ & 0.356 \\
\hline Fishing & $32.1(44.8)$ & $34.4(59.6)$ & $30.2(25.7)$ & 0.397 \\
\hline NTFP gathering and handicraft selling ${ }^{a}$ & $1.2(3.6)$ & $1.1(4.0)$ & $1.3(3.3)$ & 0.739 \\
\hline Permanent wage labor ${ }^{a}$ & $10.7(41.8)$ & $12.3(51.1)$ & $9.2(31.7)$ & 0.508 \\
\hline Casual wage labor ${ }^{a}$ & $0.5(3.2)$ & $0.4(2.6)$ & $0.6(3.7)$ & 0.458 \\
\hline Other $^{\mathrm{b}}$ & $6.9(44.5)$ & $6.5(21.4)$ & $7.3(57.7)$ & 0.872 \\
\hline Total & $112(118)$ & $120(120)$ & $104(115)$ & 0.238 \\
\hline \multicolumn{5}{|c|}{ Current income per adult equivalent per month - post-cyclone (F\$): } \\
\hline Cropping & $34.9(59.6)$ & $38.9(55.1)$ & $31.3(63.2)$ & 0.245 \\
\hline Fishing & $21.6(33.6)$ & $24.7(42.5)$ & $18.8(22.8)$ & 0.115 \\
\hline NTFP gathering and handicraft selling ${ }^{a}$ & $3.2(10.6)$ & $3.4(10.3)$ & $3.1(11.0)$ & 0.796 \\
\hline Permanent wage labor ${ }^{a}$ & $10.1(40.9)$ & $11.5(50.0)$ & $9.0(30.9)$ & 0.578 \\
\hline Casual wage labor ${ }^{a}$ & $0.9(5.4)$ & $0.5(2.9)$ & $1.3(6.9)$ & 0.184 \\
\hline Other $^{b}$ & $3.0(12.3)$ & $4.3(15.3)$ & $1.9(8.8)$ & 0.073 \\
\hline Total & $73.7(83.2)$ & $83.2(85.6)$ & $65.3(80.3)$ & 0.050 \\
\hline \multicolumn{5}{|c|}{ Household characteristics a year ago - pre-cyclone: } \\
\hline Land per adult equivalent (acre) & $1.1(1.5)$ & $1.1(1.4)$ & $1.1(1.5)$ & 0.949 \\
\hline Fishing capital per adult equivalent $(\mathrm{F} \$)$ & $107(423)$ & $141(576)$ & $77(211)$ & 0.169 \\
\hline Adults' secondary education dummy & $0.83(0.37)$ & $0.82(0.39)$ & $0.85(0.36)$ & 0.492 \\
\hline Household size (adult equivalent) & $4.9(2.2)$ & $4.8(2.1)$ & $5.0(2.3)$ & 0.354 \\
\hline Age of household head & $48.6(13.9)$ & $50.5(14.0)$ & $46.9(13.7)$ & 0.022 \\
\hline Female head dummy & $0.12(0.33)$ & $0.12(0.33)$ & $0.12(0.32)$ & 0.913 \\
\hline \multicolumn{5}{|c|}{ B. Household NTFP gathering and handicraft sales by quarter. } \\
\hline & Pre-cyclone & & Post-cyclone & \\
\hline & Period 1 & Period 2 & Period 3 & Period 4 \\
\hline \multicolumn{5}{|l|}{ Participation ( $n=223)$ : } \\
\hline NTFP gathering & $0.58(0.49)$ & $0.00(0.07)$ & $0.11(0.32)$ & $0.22(0.41)$ \\
\hline Handicraft sales & $0.12(0.33)$ & $0.12(0.32)$ & $0.19(0.39)$ & $0.22(0.42)$ \\
\hline \multicolumn{5}{|c|}{ Revenues per adult equivalent per month $(F \$)(n=223)$ : } \\
\hline NTFP gathering & $0.81(2.72)$ & $0.00(0.00)$ & $0.29(1.20)$ & $0.81(3.48)$ \\
\hline Handicraft sales & 0.73 (3.29) & $0.53(2.34)$ & $1.23(3.87)$ & $3.86(12.2)$ \\
\hline
\end{tabular}

${ }^{a}$ Pre-cyclone and post-cyclone incomes are for periods 1 and 4, respectively.

${ }^{b}$ Other income consists of shop profit, livestock selling, and other self-employment activities like middleman.

${ }^{\mathrm{c}}$ Results with a 5\% significance level are bolded. Household means are shown along with standard deviations in parentheses. In panel B, six handicraft villages are covered and revenues are for all households, not participants. 
Table 3. Determinants of log fishing revenues per adult equivalent per month - First-difference.

\begin{tabular}{|c|c|c|c|c|c|c|c|c|c|c|}
\hline & \multicolumn{2}{|c|}{ All } & \multicolumn{2}{|c|}{ Non-victims } & \multicolumn{2}{|c|}{ Victims } & \multicolumn{2}{|c|}{$\begin{array}{l}\text { No/small crop } \\
\text { damage }\end{array}$} & \multicolumn{2}{|c|}{$\begin{array}{l}\text { Large crop } \\
\text { damage }\end{array}$} \\
\hline & (1) & (2) & (3) & (4) & (5) & (6) & (7) & (8) & (9) & (10) \\
\hline \multicolumn{11}{|l|}{ Household-level shocks: } \\
\hline Housing partially damaged dummy & $\begin{array}{l}-0.087 \\
(0.093)\end{array}$ & $\begin{array}{r}-0.141 \\
(0.094)\end{array}$ & & & & & $\begin{array}{l}-0.111 \\
(0.142)\end{array}$ & $\begin{array}{r}-0.170 \\
(0.157)\end{array}$ & $\begin{array}{l}-0.061 \\
(0.106)\end{array}$ & $\begin{array}{r}-0.053 \\
(0.121)\end{array}$ \\
\hline $\begin{array}{l}\text { Housing completely damaged } \\
\text { dummy }\end{array}$ & $\begin{array}{l}-0.126 \\
(0.154)\end{array}$ & $\begin{array}{l}-0.276 \\
(0.192)\end{array}$ & & & $\begin{array}{r}-0.021 \\
(0.163)\end{array}$ & $\begin{array}{l}-0.082 \\
(0.171)\end{array}$ & $\begin{array}{l}-0.977 \text { * } \\
(0.466)\end{array}$ & $\begin{array}{l}-1.079 * \\
(0.477)\end{array}$ & $\begin{array}{r}0.104 \\
(0.151)\end{array}$ & $\begin{array}{r}0.021 \\
(0.212)\end{array}$ \\
\hline $\begin{array}{l}\text { Log crop damage per adult } \\
\text { equivalent }(F \$)\end{array}$ & $\begin{array}{l}0.066 \text { * } \\
(0.033)\end{array}$ & $\begin{array}{r}0.064 \\
(0.043)\end{array}$ & $\begin{array}{r}0.051 \\
(0.049)\end{array}$ & $\begin{array}{r}0.043 \\
(0.059)\end{array}$ & $\begin{array}{r}0.067 \\
(0.041)\end{array}$ & $\begin{array}{r}0.049 \\
(0.061)\end{array}$ & $\begin{array}{r}0.065 \\
(0.068)\end{array}$ & $\begin{array}{r}0.039 \\
(0.080)\end{array}$ & $\begin{array}{l}0.169 * \\
(0.078)\end{array}$ & $\begin{array}{l}0.177 \text { * } \\
(0.081)\end{array}$ \\
\hline \multicolumn{11}{|l|}{ Group-level shocks: } \\
\hline $\begin{array}{l}\text { Proportion of housing partially } \\
\text { damaged in the kin group }\end{array}$ & & $\begin{array}{r}0.269 \\
(0.212)\end{array}$ & & $\begin{array}{l}0.826 \text { * } \\
(0.361)\end{array}$ & & $\begin{array}{l}-0.387 \\
(0.248)\end{array}$ & & $\begin{array}{r}0.271 \\
(0.427)\end{array}$ & & $\begin{array}{r}-0.028 \\
(0.263)\end{array}$ \\
\hline $\begin{array}{l}\text { Proportion of housing completely } \\
\text { damaged in the kin group }\end{array}$ & & $\begin{array}{l}0.962 \text { * } \\
(0.457)\end{array}$ & & $\begin{array}{l}1.462 \text { ** } \\
(0.495)\end{array}$ & & $\begin{array}{r}0.164 \\
(0.666)\end{array}$ & & $\begin{array}{r}0.924 \\
(0.581)\end{array}$ & & $\begin{array}{r}0.591 \\
(0.594)\end{array}$ \\
\hline $\begin{array}{l}\text { Kin-group mean of log crop damage } \\
\text { per adult equivalent }(F \$)\end{array}$ & & $\begin{array}{r}0.036 \\
(0.076)\end{array}$ & & $\begin{array}{r}0.058 \\
(0.133)\end{array}$ & & $\begin{array}{r}0.164 \\
(0.122)\end{array}$ & & $\begin{array}{r}0.187 \\
(0.154)\end{array}$ & & $\begin{array}{r}-0.040 \\
(0.093)\end{array}$ \\
\hline$F$ (p-value) & 0.000 & 0.000 & 0.000 & 0.000 & 0.007 & 0.000 & 0.000 & 0.000 & 0.007 & 0.000 \\
\hline R squared & 0.150 & 0.163 & 0.162 & 0.208 & 0.155 & 0.170 & 0.168 & 0.188 & 0.317 & 0.322 \\
\hline No. observations & 664 & 664 & 310 & 310 & 354 & 354 & 332 & 332 & 332 & 332 \\
\hline
\end{tabular}

*5\% significance, ${ }^{*} 1 \%$ significance, ${ }^{* \star *} .1 \%$ significance. Robust standard errors are in the parentheses of columns (1), (3), (5), (7), and (9) and standard errors clustered by group are in the parentheses of columns (2), (4), (6), (8), and (10). All models include a time dummy and village-time dummies. In columns (7)-(10), sample division is based on the median of crop damage value per adult equivalent. 
Table 4. Group correlations of housing rehabilitation with post-cyclone fishing and handicraft selling.

\begin{tabular}{llcc} 
& & Fishing & $\begin{array}{c}\text { Handicraft } \\
\text { selling } \\
(2)\end{array}$ \\
\hline Total revenues & All & $(1)$ & 0.088 \\
& & 0.094 & $(0.193)$ \\
& Non-victims & 0.121 & 0.094 \\
& Victims & $\mathbf{( 0 . 0 3 3 )}$ & $(0.166)$ \\
& & 0.060 & 0.003 \\
Mean revenues & All & $(0.292)$ & $(0.968)$ \\
(per adult equivalent) & & 0.030 & -0.086 \\
& Non-victims & $(0.593)$ & $(0.203)$ \\
& & 0.081 & 0.110 \\
& & $(0.154)$ & $(0.103)$ \\
& Victims & -0.050 & -0.232 \\
$\begin{array}{l}\text { Revenues per victim } \\
\text { (per adult equivalent) }\end{array}$ & & $(0.377)$ & $\mathbf{( 0 . 0 0 1 )}$ \\
$\begin{array}{l}\text { Revenues per non-victim } \\
\text { (per adult equivalent) }\end{array}$ & Non-victims & 0.231 & 0.091 \\
No. groups & & $\mathbf{( 0 . 0 0 0 )}$ & $(0.176)$ \\
\hline
\end{tabular}

Correlations (weighted by kin group size) of the proportion of housing rehabilitated among victims in the kin group with various post-cyclone revenues per month in the same kin group defined in the text are shown along with $\mathrm{p}$ values in parentheses (those with a 5\% significance level are bolded). Handicraft revenues are from six handicraft villages in periods 2-4. 
Table 5. Determinants of log handicraft revenues per adult equivalent per month - Trimmed least squares.

\begin{tabular}{|c|c|c|c|c|c|c|}
\hline \multirow[b]{2}{*}{$(n=446)$} & \multicolumn{2}{|c|}{ Periods 1 and 2} & \multicolumn{2}{|c|}{ Periods 1 and 3} & \multicolumn{2}{|c|}{ Periods 1 and 4} \\
\hline & $(1)$ & $(2)$ & $(3)$ & $(4)$ & $(5)$ & $(6)$ \\
\hline \multicolumn{7}{|l|}{ Household-level shocks: } \\
\hline Housing partially damaged dummy & $\begin{array}{r}-0.73 \\
(0.46)\end{array}$ & $\begin{array}{r}-0.74 \\
(0.47)\end{array}$ & $\begin{array}{r}-0.43 \\
(0.55)\end{array}$ & $\begin{array}{r}-0.54 \\
(0.46)\end{array}$ & $\begin{array}{r}-0.44 \\
(0.56)\end{array}$ & $\begin{array}{l}-0.89 \\
(0.58)\end{array}$ \\
\hline $\begin{array}{l}\text { Housing completely damaged } \\
\text { dummy }\end{array}$ & $\begin{array}{r}0.31 \\
(0.46)\end{array}$ & $\begin{array}{r}0.78 \\
(0.86)\end{array}$ & $\begin{array}{r}0.81 \\
(0.69)\end{array}$ & $\begin{array}{r}0.98 \\
(0.75)\end{array}$ & $\begin{array}{l}3.25 * \\
(1.34)\end{array}$ & $\begin{array}{r}1.90 \\
(1.94)\end{array}$ \\
\hline $\begin{array}{l}\text { Log crop damage per adult } \\
\text { equivalent }(\mathrm{F} \$)\end{array}$ & $\begin{array}{r}0.21 \\
(0.14)\end{array}$ & $\begin{array}{r}0.23 \\
(0.13)\end{array}$ & $\begin{array}{l}0.39 * * \\
(0.13)\end{array}$ & $\begin{array}{l}0.35 * * * \\
(0.12)\end{array}$ & $\begin{array}{r}0.16 \\
(0.16)\end{array}$ & $\begin{array}{r}0.27 \\
(0.20)\end{array}$ \\
\hline \multicolumn{7}{|l|}{ Group-level shocks: } \\
\hline $\begin{array}{l}\text { Proportion of housing partially } \\
\text { damaged in the kin group }\end{array}$ & & $\begin{array}{r}1.20 \\
(2.77)\end{array}$ & & $\begin{array}{r}1.16 \\
(1.30)\end{array}$ & & $\begin{array}{r}4.35 \\
(2.42)\end{array}$ \\
\hline $\begin{array}{l}\text { Proportion of housing completely } \\
\text { damaged in the kin group }\end{array}$ & & $\begin{array}{r}-1.88 \\
(3.13)\end{array}$ & & $\begin{array}{r}0.32 \\
(2.22)\end{array}$ & & $\begin{array}{r}1.72 \\
(3.66)\end{array}$ \\
\hline $\begin{array}{l}\text { Kin-group mean of log crop } \\
\text { damage per adult equivalent }(\mathrm{F} \$)\end{array}$ & & $\begin{array}{r}0.15 \\
(0.54)\end{array}$ & & $\begin{array}{r}0.65 \\
(0.46)\end{array}$ & & $\begin{array}{r}0.85 \\
(0.45)\end{array}$ \\
\hline Wald ( $p$-value) & 0.022 & 0.063 & 0.000 & 0.000 & 0.000 & 0.000 \\
\hline Loss function & 19.3 & 20.2 & 38.7 & 53.3 & 82.7 & 88.0 \\
\hline
\end{tabular}

${ }^{*} 5 \%$ significance, ${ }^{* *} 1 \%$ significance, ${ }^{* * *} .1 \%$ significance. Robust standard errors are in parentheses. All models include a time dummy and village-time dummies. 